\title{
Changes in blood chemistry values of the cattle with associative course of leukemia and brucellosis
}

\author{
Vasiliy Vlasenko ${ }^{1,2, *}$, Sayat Baiseitov ${ }^{1}$, Valentina Pleshakova ${ }^{1}$, and Irina Alekseeva ${ }^{1}$ \\ ${ }^{1}$ Veterinary Microbiology, Infectious and Invasive Diseases Department, Omsk State Agrarian University named after P.A. Stolypin, \\ 644008 Omsk, Russia \\ ${ }^{2}$ Veterinary Medicine Department, Omsk Agrarian Scientific Center, 644001 Omsk, Russia
}

\begin{abstract}
This paper describes the results obtained when the characteristics of metabolic process changes in leukemia, including brucellosis-complicated leukemia, were studied. To do it, 50 blood serum samples were taken from cows with specific antibodies against bovine leukemia virus (BLV) under the results of immunological diffusion reactions (IDR), indirect immunofluorescence (IIF) and enzyme-linked immunosorbent assay (ELISA). All samples were serologically tested to detect a number of bacterial infections resulted in a possibility to establish that the BLV carrier state in most animals is combined with a bacterial infection, especially brucellosis (46\%), chlamydia (20\%), paratuberculosis (12\%) and campylobacteriosis $(8 \%)$. At the next stage, 3 groups of 10 animals each were formed to study the metabolic process level, i.e. clinical healthy animals with no specific antibodies revealed during diagnostic tests for leukemia and other infections (Group 1); BLV carriers (Group 2); brucellosis- and virus carrier animals (Group 3). Analysis of the blood chemistry values obtained for the experimental groups showed an uneven path of changes, especially for the protein and fat metabolism parameters. The difference was in albumin and cholesterol concentrations reduced in BLV infected animals, while their level was significantly increased in animals with leukemia associated with brucellosis, on the contrary.
\end{abstract}

\section{Introduction}

Bovine leukemia is a serious problem for cattle breeding in the Republic of Kazakhstan, like in some other countries of the world where this disease is quite widespread especially where no large-scale eradication programs have been introduced. For example the prevalence of BLV in US dairy cattle has been increasing over the past decades, with the most current report estimating that $94 \%$ of herds and $42 \%$ of dairy cows are positive for BLV antibodies [1-6]. In fact, the efforts made to implement control measures and national campaigns intended to eliminate the infection in some Western European countries enabled to achieve a complete elimination of this disease [7-9].

Virus infection results in significant economic losses for a variety of causes: a decrease in the milk production quality and quantity, untimely death or forced culling and slaughter of animals, shortage in young stock, loss of its breeding worth and implementation restrictions, anti-leukemia measure costs, high levels of infectious complications, as well as fertility inability [10-13].

It is known that the development of the leukemia process occurs against the background of deep violations of the immune mechanisms, especially the parameters of the cellular system [14-17]. However, the infectious and inflammatory complications occurred quite often in BLV infected animals add variety to the disease, first of all causing the immunosuppressive body state, and the immunostimulating effect in some cases [18].

The results obtained by some researchers [19] showed that a decrease in the level of metabolic processes along with immunity defects are developed in bovine leukemia virus (BLV) infected animals and animals with leukemia. Besides, leukemia virus infected animals develop a higher susceptibility to various taxonomic affiliation pathogens (viruses, bacteria, mycoplasmas, entozoic and ectozoic parasites). It is worth mentioning that associative manifestation data for some chronical infections have been intensively accumulated recently, in particular, for bovine leukemia and tuberculosis, as well as leukemia and chlamydia combined with parasites [20, 21].

So, it was established that the immunobiological and metabolic status parameters of the body in animals decreased in the cases of spontaneous combined course of bovine leukemia and tuberculosis [20]. Associative microparacytocenoses usually follow with severe outcomes, and it should be pointed out that the researchers disregard both the synergistic action of particular pathogens and the antagonistic interaction between the parasitocenosis members significantly affecting immunobiochemical parameters of a macroorganism as a result.

Corresponding author: vvs-76@1ist.ru 
However, the associative course of leukemia with other infectious diseases and, in particular, with cattle brucellosis is not addressed in these works. At the same time, the associative course of bovine leukemia and brucellosis compromises the stock selecting and breeding, and in general, the genetic potential and viability of breed herds. Therefore, to study the characteristics of changes in blood chemistry values in cattle with bacterial infection complicated leukemia is of particular interest.

\section{Material and Research Methods}

The cows of the Red Steppe and Holstein-Friesian cattle bred in various farms of the North Kazakhstan Region in the Republic of Kazakhstan were used for our study.

BLV carriage in cows was determined with the help of agar gel immunodiffusion reactions - IDR (manufactured by "Biok Company - Kursk Biofactory" Federal State-Owned Enterprise, Russia), enzyme-linked immunosorbent assay - ELISA (manufactured by ID Vet, France) and indirect immunofluorescence - IIF; ELISA (manufactured by AniGen, Korea), rose bengal test (RBT), agglutination reaction (AR) and complement-fixation test (CFT) with a single antigen (manufactured by "Antigen" Scientific Industrial Enterprise, Kazakhstan) and IIF were used to diagnose brucellosis. ELISA (paratuberculosis, chlamydia) to diagnose other bacterial infections with the help of commercial ID Vet kits, as well as IIF (chlamydia, anaplasmosis, campylobacteriosis and Q fever).
All tests were performed under the instructions for the use of diagnostic kits to detect specific antibodies in blood serum.

Blood parameters of mineral (iron, magnesium, calcium, inorganic phosphorus), protein (total protein, albumin, urea), lipid (cholesterol), carbohydrate (glucose), and purine (uric acid) metabolisms were determined with the help of biochemical studies.

The enzyme immunoassay results were registered and interpreted using an ELISA analyzer - Multiscan FX ("Thermo Scientific"). A Stat Fax 4500 semi-automatic biochemical analyzer (USA) with reagent kits manufactured by DiAKiT LLP (the Republic of Kazakhstan) and DIAKON-DS JSC (Russia) was used to study blood serum in accordance with the instructions for their use.

The data obtained were statistically processed to determine arithmetic mean (M) and to calculate arithmetic mean errors (m). The Student t-test was used to assess the statistical significance (p) between the two mean values of Mx and My. Differences in results were deemed as statistically significant at a significance level of $\mathrm{p} \leq 0.05$.

\section{Results and Discussion}

At the initial stage of the study, the blood serum sampled from 50 animals having antibodies against the leukemia virus detected simultaneously with the help of IDR, ELISA and IIF, were tested diagnostically to detect any other infectious diseases: anaplasmosis, brucellosis, campylobacteriosis, chlamydia, paratuberculosis and Q fever. The results are specified in Table 1.

Table 1. Results of complex diagnostic studies of blood serum sampled from BLV carriers

\begin{tabular}{|l|c|c|c|c|c|c|}
\hline \multirow{2}{*}{ Diagnostic tests (n=50) } & \multicolumn{5}{|c|}{ Revealed antibodies, samples (\%) } \\
\cline { 2 - 7 } & ELISA & IIF & ELISA+IIF & RBT & AR & CFT \\
\hline Brucellosis & $19(38)$ & $23(46)$ & $19(38)$ & $22(44)$ & $20(40)$ & $19(38)$ \\
\hline Chlamydia & $5(10)$ & $9(18)$ & $4(8)$ & - & - & - \\
\hline Paratuberculosis & $6(12)$ & - & - & - & - & - \\
\hline Anaplasmosis & - & $2(4)$ & - & - & - & - \\
\hline Q fever & - & 0 & - & - & - & - \\
\hline Campylobacteriosis & - & $4(8)$ & - & - & - & - \\
\hline
\end{tabular}

Table 1 shows that the BLV carriage was combined with brucellosis infection in most cases. So, specific antibodies were detected in total of 23 blood serum samples (46\%), where 19 were positive in RBT, CFT, AR, ELISA and IIF, 3 were positive only in RBT and IIF, and 1 was positive in AR, ELISA and IIF. It should be noted that chlamydia antibodies were detected in 2 samples, in addition to brucellosis antibodies.

Besides, it was established with ELISA and IIF that antibodies against other bacterial diseases were detected in other 17 blood sera studied where chlamydia could be especially distinguished. Specific antibodies against this bacterial infection were detected in 10 samples (20\%), of which 5 were positive in ELISA, in 9 were positive in IIF and in 4 were positive simultaneously in ELISA and IIF. It should be noted that the carriage of other bacterial infections was simultaneously detected in 4 of 5 cases when specific antibodies were absent under the ELISA results but were identified using IIF.

As it was noted above, antibodies against brucellosis were detected in 2 samples, and antibodies against anaplasmosis and campylobacteriosis were detected in one sample each along with chlamydia antibodies.

A number of researchers specify that detection of bovine leukemia virus carriers between animals on time can be difficult both due to not always reliable diagnostic tools and because of the associative infection manifestation that can facilitate the occurrence of nonspecific reactions [20].

Our comprehensive diagnostic laboratory studies suggested that brucella antibodies were identified most often with the indirect immunofluorescence assay (IFA) during the blood serum test and were diagnosed in the fewest amount of tests with ELISA and CFT. At the same time, chlamydia antibodies were detected in the 
largest number of blood serum samples with IFA, and in the fewest number with ELISA.

Thirty cows were selected and divided into 3 groups at the next stage of the study. Group 1 consisted of clinically healthy animals $(n=10)$ with no specific antibodies against leukemia and bacterial infections in diagnostic tests (a control). Group 2 included 10 animals that were leukemia positive under the results of diagnostic tests using IDR, ELISA and IIF (BLV carriers). Group 3 also included $10 \mathrm{BLV}$ infected animals but they were brucellosis positive in RBC, AR, CFT, ELISA, and IIF in contrast with Group 2.

Blood chemistry values were determined for animals in all groups. The results are shown in Table 2.

An unequal parameter variation curve was found in the cattle of the experimental groups compared with the control one when protein metabolism parameters were analyzed. So, while there was a decrease in the total protein and albumin concentration in blood serum of the BLV carriers, the animals that were both brucellosis and virus carriers had an increase in their content, on the contrary. We think that the latter may be due to the fact that so-called "pathological proteins" or monoclonal immunoglobulins are formed during the associated course of bovine leukemia and brucellosis in the body of sick animals which in their turn are the products of secretion of one clone of B-lymphocytes or plasma cells.

The most signified differences were detected in the albumin amount. In particular, this parameter significantly increased up to $63.3 \pm 3.5 \mathrm{~g} / \mathrm{l}$ in the associated viral infection versus $38.1 \pm 1.4 \mathrm{~g} / \mathrm{l}(\mathrm{p}<0.01)$ in healthy animals, whereas it decreased to $23.9 \pm 1.5$ with a high confidence degree in BLV infected animals.

A significant albumin increase in the serum of cows with a combined course of viral and bacterial infection, and in particular, bovine leukemia and brucellosis, may be associated with the infection process increase during the associated disease course.

At the same time, the total protein changes did not reach a relevant difference. Thus, the level of this parameter equaled $71.8 \pm 1.7 \mathrm{~g} / \mathrm{l}$ in clinically healthy cows, and it fell to $66.1 \pm 6.0 \mathrm{~g} / \mathrm{l}$ in leukemia virus carriers but it was increased up to $82.1 \pm 5.2 \mathrm{~g} / \mathrm{l}$ in animal carriers having a bacterial infection complication, on the contrary.

Table 2. Results of serum chemistry studies in cattle with leukemia and brucellosis infection, $M \pm m$

\begin{tabular}{|l|c|c|c|}
\hline \multirow{2}{*}{\multicolumn{1}{|c|}{ Blood Chemistry Values }} & \multicolumn{3}{|c|}{ Group of the Animals } \\
\cline { 2 - 3 } & Healthy & BLV Carriers & $\begin{array}{c}\text { Leukemia and Brucellosis } \\
\text { Infection }\end{array}$ \\
\hline Total Protein, g/l & $71.8 \pm 1,7$ & $66.1 \pm 6.0$ & $82.1 \pm 5.2$ \\
\hline Albumins, g/l & $38.1 \pm 1.4$ & $23.9 \pm 1.5^{\mathrm{b}}$ & $63.3 \pm 3.5^{\mathrm{b}}$ \\
\hline Calcium, mmol/l & $2.7 \pm 0.1$ & $1.9 \pm 0.1^{\mathrm{b}}$ & $2.4 \pm 0.1^{\mathrm{a}}$ \\
\hline Phosphorus, mmol/l & $1.5 \pm 0.1$ & $2.3 \pm 0.2^{\mathrm{a}}$ & $1.5 \pm 0.1$ \\
\hline Magnesium, mmol/l & $5.1 \pm 0.7$ & $4.0 \pm 0.7$ & $4.9 \pm 0.7$ \\
\hline Iron, $\mathrm{mmol} / \mathrm{l}$ & $34.8 \pm 1.8$ & $33.4 \pm 1.9$ & $32.5 \pm 1.6$ \\
\hline Glucose, $\mathrm{mmol} / \mathrm{l}$ & $2.8 \pm 0.1$ & $2.8 \pm 0.1$ & $3.0 \pm 0.3$ \\
\hline Cholesterol, $\mathrm{mmol} / \mathrm{l}$ & $3.6 \pm 0.3$ & $3.0 \pm 0.4$ & $4.9 \pm 0.5^{\mathrm{a}}$ \\
\hline Urea, $\mathrm{mmol} / \mathrm{l}$ & $4.9 \pm 0.7$ & $4.7 \pm 0.5$ & $5.5 \pm 0.8$ \\
\hline Uric Acid, $\mu \mathrm{mol} / \mathrm{l}$ & $63.7 \pm 6.9$ & $73.8 \pm 5.9$ & $67.2 \pm 4.4$ \\
\hline
\end{tabular}
${ }^{\mathrm{a}} \mathrm{p}<0.05,{ }^{\mathrm{b}} \mathrm{p}<0.01$.

The same change trajectory was observed in the urea and cholesterol content in animals included into the experimental groups compared with the control one, but only the concentration of the latter parameter reached a significant difference in cows with leukemia-associated infection and amounted to $4.9 \pm 0.5 \mathrm{mmol} / \mathrm{l}$ against $3.6 \pm$ $0.3 \mathrm{mmol} / \mathrm{l}(\mathrm{p}<0.05)$ in healthy cattle.

In our opinion, this specified tendency is most probably related to the fact that cholesterol molecules are not only the main structures in the cell membranes but also contribute to the enhanced macrophage function and, in particular, pathogenic bacteria phagocytosis.

At the same time, the blood serum urea concentration in bovine leukemia virus carriers was only slightly lower than the same parameter in clinically healthy animals (respectively: $4.9 \pm 0.7,4.7 \pm 0.5 \mathrm{mmol} / \mathrm{l}$ ), and on the contrary, it increased up to $5.5 \pm 0.8 \mathrm{mmol} / \mathrm{l}$ in the cases of bacterial infection complications.

Serum uric acid did not have a significant change, although this parameter had a tendency to be increased in cows from both study groups. So, its concentration was $73.8 \pm 5.9 \mu \mathrm{mol} / \mathrm{l}$ in bovine leukemia virus carriers, and $67.2 \pm 4.4 \mu \mathrm{mol} / \mathrm{l}$ in animals with a combined bacterial and viral infection course, while this parameter was at the level of $63.7 \pm 6.9 \mu \mathrm{mol} / \mathrm{l}$ in the control group.

No significant difference was detected for serum glucose found to be the same in both clinically healthy cows and virus carriers $(2.8 \pm 0.1 \mathrm{mmol} / \mathrm{l})$, while it was insignificantly increased up to $3.0 \pm 0.3 \mathrm{mmol} / \mathrm{l}$ in animals that were simultaneously brucella carriers.

The analysis of blood chemistry values also detected some deviations in mineral metabolism manifested by a significant decrease in the total calcium level down to $1.9 \pm 0.1 \mathrm{mmol} / \mathrm{l}$ in $\mathrm{BLV}$ carriers against $2.7 \pm 0.1$ $\mathrm{mmol} / \mathrm{l}(\mathrm{p}<0.01)$ in the control group against a background of a noticeable inorganic phosphorus concentration increase (respectively, $2.3 \pm 0.2,1.5 \pm 0.1$ $\mathrm{mmol} / \mathrm{l} ; \mathrm{p}<0.05)$.

A trend towards a significant decrease in the total calcium content was also observed for the associative manifestation of leukemia infection, however, the difference was that the inorganic phosphorus amount remained unchanged. So, the level of serum calcium decreased up to $2.4 \pm 0.1 \mathrm{mmol} / \mathrm{l}(\mathrm{p}<0.05)$ in the 
leukemia-brucellosis infected cattle, and inorganic phosphorus was $1.5 \pm 0.1 \mathrm{mmol} / \mathrm{l}$, the same as in animals of the control group.

The magnesium and iron concentration in the blood serum of the cattle included into the experimental groups as compared with the same parameters in healthy cows had a tendency to be reduced without a significant difference. In particular, a more pronounced magnesium concentration decrease to $4.0 \pm 0.7 \mathrm{mmol} / \mathrm{l}$ was observed in bovine leukemia virus infected animals versus $5.1 \pm 0.7 \mathrm{mmol} / \mathrm{l}$ in the control group, while its concentration remained almost unchanged and equaled to $4.9 \pm 0.7 \mathrm{mmol} / \mathrm{l}$ during the associative course of leukemia-brucellosis infection at the same time.

The level of other iron microelement decreased insignificantly in cows of both test groups to $33.4 \pm 1.9$ and $32.5 \pm 1.6 \mathrm{mmol} / \mathrm{l}$, respectively, versus $34.8 \pm 1.8$ $\mathrm{mmol} / \mathrm{L}$ in clinically healthy animals.

\section{Conclusion}

According to the results obtained, it can be concluded that the associated course of leukemia infection most often occurs with the following bacterial infection pathogens as brucellosis, chlamydia, paratuberculosis and campylobacteriosis.

It has been found out that the biochemical status of BLV infected animals is characterized with a decrease in the protein, fat and mineral metabolism intensity. Significant changes accompanied with a decrease in the albumin and calcium concentration can be especially noted against a significant increase in the inorganic phosphorus content.

On the contrary, the associative course of leukemia infection with brucellosis detected in $46 \%$ of leukemia virus carriers was accompanied with an increase in the protein and fat metabolism intensity as evidenced with a significant increase in the albumin and cholesterol level.

\section{References}

1. G. Gutierrez, I. Alvarez, R. Politzki, M. Lomo, F. Rondelli, N. Fondevila, K. Trono, Vet. Microbiol., 151(3-4), 255-263 (2011)

2. R.V. Ndou, F. Sejesho, B.M. Dzoma, L.E. Motsei, M. Nyirenda, F.R. Bakunzi, J. Hum. Ecol., 36(1), 53-55 (2011)

3. K. Murakami, S. Kobayashi, M. Konishi, K. Kameyama, T. Tsutsui, J. Vet. Med. Sci., 75(8), 1123-1126 (2013)

4. R.M. LaDronka, S. Ainsworth, M.J. Wilkins, B. Norby, T.M. Byrem, P.C. Bartlett, Vet. Med. Int., 4, 1-8 (2018)

5. A. Krasikov, V. Vlasenko, V. Pleshakova, I. Alekseeva, The Fifth technological order: prospects for the development and modernization of the Russian agro-industrial sector, 393 (Atlantis Press, Paris, 2019)

6. L. Usenova, A. Nurpeisova, R. Akil'zhanov, Global Science and Innovations IV, ed. E. Atasoy (DARA, Astana, 2018)

7. S. More, A. Botner, A. Butterworth, P. Calistri, K. Depner, S. Edwards, B. Garin-Bastuji, M. Good, C.G. Schmidt, V. Michel, M.A. Miranda, S.S. Nielsen, M. Raj, L. Sihvonen, H. Spoolder, J.A. Stegeman, H-H. Thulke, A. Velarde, P. Willeberg, C. Winckler, F. Baldinelli, A. Broglia, B. Beltran-Beck, L. Kohnle, D. Bicout, EFSA J., 15(8), 4956 (2017)

8. J. Ruggiero, P.C. Bartlett, Veterinary Medicine Int., 6, 3202184 (2019) https://doi.org/10.1155/2019/ $\underline{3202184}$

9. European Food Safety Authority Panel on Animal Health and Welfare, Scientific opinion on Enzootic bovine leukosis, EFSA J., 13(7), 4188 (2015)

10. N. Sandev, M. Koleva, R Binev, D. Ilieva, Veterinarski Archiv, 76, 411-416 (2004)

11. P.C. Bartlett, B. Norby, T.M. Byrem, A. Parmelee, J.T. Ledergerber, R.J. Erskine, J. Dairy Sci., 96, 1591-1597 (2013)

12. O. Nekouei, J. VanLeeuwen, H. Stryhn, D. Kelton, G. Keefe, Prev. Vet. Med., 133, 1-9 (2016)

13. L. Fogel, O. Kozyrenko, V. Kuzmin, E. Dzhavadov, Yu. Danko, Indo-Amer. J. of Pharmaceutical Sciences, 6(3), 5278-5281 (2019)

14. N. Gillet, A. Florins, M. Boxus, C. Burteau, A. Nigro, F. Vandermeers, H. Balon, A.B. Bouzar, J. Defoiche, A. Burny, M. Reichert, R. Kettmann, L. Willems, Retrovirology, 4, 18 (2007)

15. M.C. Frie, P.M. Coussens, Immunol. Immunopathol., 163(3-4), 103-114 (2015)

16. S. Konnai, S. Murata, K. Ohashi, J. Vet. Med. Sci., 79(1), 1-5 (2017)

17. A.I. Pavlova, P.N. Smirnov, L.P. Koriakina, T.V. Garmatarova, O.S. Kotliarova, V.E. Razymnaia, P.L. Romanov, Innovations and food safety, 1(15), 17-21 (2017)

18. S. Baiseitov, V. Vlasenko, Perm Agrarian Bull., 4(28), 89-94 (2019)

19. M.P. Semenenko, N.Yu. Bassova, E.V. Kuzminova, Veterinary medicine in Kuban, 2, 22-23 (2011)

20. S.N. Mager, A.S. Donchenko, Bull. of the Russian Academy of Agricultural Sciences, 5, 66-67 (2005)

21. A.P. Poryvayeva, M.V. Petropavlovskiy, N.A. Bezborodova, A.S. Romanova, A.G. Isayeva, A.S. Krivonotova, V.V. Kozhukhovskaya, Legal regulation issues in veterinary medicine, 4, 40-44 (2019) 